\title{
APONTAMENTOS ACERCA DAS OBRIGAÇÕES PROPTER REM
}

\section{NOTES ON PROPTER REM OBLIGATION}

\section{Milena Donato Oliva ${ }^{1}$}

\section{Resumo}

O presente artigo, a partir da revisão da literatura sobre o tema e das decisões dos tribunais pátrios, examina o regime jurídico das obrigações propter rem, buscando identificar as consequências da transferência do direito real em relação ao polo passivo da obrigação propter rem constituída anteriormente a essa transmissão. O artigo analisa a problemática da sucessão da obrigação propter rem no âmbito da propriedade horizontal e também no que tange à responsabilidade ambiental. Uma vez definida a obrigação propter rem e analisada a questão de sua transmissibilidade, o artigo busca diferenciá-la das chamadas obrigações com eficácia real e dos ônus reais, bem como averiguar se pode ser constituída livremente pela autonomia privada ou se está sujeita aos princípios da taxatividade e da tipicidade, peculiares aos direitos reais.

Palavras-chave: obrigações propter rem; propriedade horizontal; responsabilidade ambiental; ônus reais; taxatividade.

\begin{abstract}
The present article, based on a review of literature on the subject and decisions of country courts, examines the legal regime of propter rem obligations, aiming at identifying the consequences of the transfer of the real right in relation to the liability of the propter rem obligation constituted before this transmission. The article analyzes the issue of propter rem obligation's succession in the field of horizontal property and also in relation to environmental liability. Once the propter rem obligation is defined and the question of its transmissibility analyzed, the article seeks to differentiate it from the so-called obligations with real effectiveness and encumbrances, as well as to determine whether it can be freely constituted by private autonomy or whether it has to follow a legally required form.
\end{abstract}

Keywords: propter rem obligation; horizontal property; environmental liability; encumbrances; real right legally required form.

\footnotetext{
${ }^{1}$ Doutora em Direito Civil pela UERJ. E-mail: mdo@tepedino.adv.br
} 


\section{INTRODUÇÃO}

A obrigação propter rem, também denominada obrigação real, mista, ob rem, in rem ou rei cohaerens, origina-se da titularidade de uma situação jurídica real ou possessória. A definição da sua natureza jurídica suscita dúvidas, não sendo pacífico seu enquadramento no âmbito dos direitos reais ou pessoais. Ao mesmo tempo em que se associa à titularidade de um direito real ou ao exercício da posse, de maneira que o devedor propter rem é determinado a partir de sua relação com a coisa, consubstancia dever que vincula pessoalmente o sujeito, e para cujo cumprimento este responde com todo o seu patrimônio.

Sem prejuízo dessa discussão, a principal controvérsia acerca das obrigações propter rem diz respeito à sua sucessão quando há transmissão, a título singular, do direito real ao qual se vincula. Afigura-se incontroverso ser o adquirente devedor das obrigações reais nascidas após se tornar titular da situação jurídica subjetiva real da qual emerge a obrigação propter rem. O debate refere-se às consequências da transferência do direito real em relação ao polo passivo da obrigação propter rem constituída (mas não cumprida) anteriormente a essa transmissão. Indaga-se se os efeitos do inadimplemento da obrigação propter rem pelo antigo titular ou possuidor transmitem-se ao adquirente ou se este, ao revés, apenas se encontra obrigado ao cumprimento das obrigações propter rem nascidas após se tornar titular de situação real ou possessória sobre a coisa, de maneira que o descumprimento do seu antecessor não the contaminaria.

O presente artigo examina o problema da sucessão das obrigações propter rem de maneira geral e também analisa duas situações concretas, quais sejam, a responsabilidade do adquirente, na propriedade horizontal, pelos encargos condominiais vencidos anteriormente à aquisição da unidade autônoma, e a responsabilidade ambiental do adquirente pelas infrações cometidas pelo alienante à luz do Código Florestal.

Uma vez definida a obrigação propter rem e analisada a questão de sua transmissibilidade, importa distingui-la das chamadas obrigações com eficácia real e dos ônus reais, bem como averiguar se pode ser constituída livremente pela autonomia privada ou se está sujeita aos princípios da taxatividade e da tipicidade, peculiares aos direitos reais. Ao seguir esse itinerário traçado a partir dos problemas concretos enfrentados pelos tribunais pátrios e suscitados pela doutrina especializada, o presente artigo tem por objetivo sistematizar o regime jurídico das obrigações propter rem no direito brasileiro. 


\section{DISTINÇÃO ENTRE DIREITOS REAIS E OBRIGACIONAIS}

A distinção entre direitos reais e obrigacionais tem por base a estrutura dessas situações jurídicas subjetivas, as quais, sob perspectiva funcional, integram a categoria mais ampla das situações patrimoniais, que se contrapõe às situações jurídicas existenciais. O peso dessa tradicional divisão estrutural tem sido revisto pela doutrina (TEPEDINO, 2006, p. 136 e 137; MAURO, 2005, p. 69 e ss.; MAURO, 2013, p. 39-56; RENTERIA, 2016, p. 7-83), que destaca a necessidade de aplicação de disciplina unitária para as situações jurídicas subjetivas reais e obrigacionais, já que possuem mesma função (PERLINGIERI, 2002, p. 201-202).

É de se ressaltar, nessa direção, que a classificação tradicionalmente adotada entre direitos reais e obrigacionais, fundada em elementos exclusivamente estruturais e estáticos, mostra-se insuficiente para a valoração dos atos praticados pela autonomia privada. Com efeito, a disciplina jurídica aplicável não será definida apenas com base no enquadramento como direito pessoal ou real, mas, e principalmente, a partir da análise valorativa do ato de autonomia privada (OLIVA E RENTERIA, 2015, p. 103-136). Da unidade axiológica do ordenamento jurídico decorre o caráter unitário do processo hermenêutico de valoração do ato de autonomia privada. Por isso que, independentemente da natureza real ou pessoal, qualquer situação jurídica subjetiva é tutelada pelo ordenamento somente se for orientada à realização de interesses que estejam em consonância com os valores inscritos na Constituição da República (RENTERIA, 2016, p. 81-82; TEPEDINO, 1993, p. 85). Configura-se, assim, do ponto de vista axiológico, um direito comum das situações patrimoniais (PERLINGIERI, 2002, p. 201-202).

De toda sorte, mostra-se oportuno investigar as diferenças estruturais entre direitos reais e pessoais que se vinculam à diversa disciplina jurídica aplicável a cada uma dessas situações. Tradicionalmente se afirma que os direitos reais têm por objeto imediato uma coisa, com a qual estabelece seu titular um liame direto, sem intermediário (SCAPEL, 2002, p. 30).

Os direitos obrigacionais, ao seu turno, apresentam, entre o credor e o objeto do direito (a prestação), o devedor, do qual aquele depende para a satisfação de seu direito (TEPEDINO, 1993, p. 58). Em outras palavras, é imprescindível a cooperação do devedor para a realização do direito obrigacional (NONATO, 1959, p. 43; JÚNIOR, 2003, p. 131-133).

Essa primeira diferença, contudo, tem sido revisitada pela doutrina (RENTERIA, 2016, p. 7-83), que ressalta existirem direitos pessoais em que a satisfação do credor ocorre pelo aproveitamento direto da coisa, a exemplo da locação ou do comodato, ao mesmo tempo em 
que haveria direitos reais nos quais o titular dependeria, para ter seu interesse realizado, da cooperação de outrem, como na hipoteca e na servidão negativa.

A necessidade de cooperação, assim, não é exclusiva dos direitos pessoais, sendo igualmente importante no campo dos direitos reais, notadamente nos direitos reais na coisa alheia. Há de se admitir, diante disso, a aplicação dos princípios do direito das obrigações às relações jurídicas reais naquilo em que forem pertinentes para a disciplina do dever de colaboração entre os diversos centros de interesses envolvidos (RENTERIA, 2016, p. 36).

Como segunda distinção tradicional, entende-se que as situações obrigacionais possuem caráter relativo (GOMES, 2007, p. 46), vinculando apenas credor e devedor, em contraposição à natureza absoluta das situações jurídicas reais (VARELA, 2000, p. 182). Afirmase que os direitos obrigacionais se referem a um dever específico dirigido a pessoa determinada ou determinável, ao passo que os direitos reais correspondem ao dever geral de abstenção (obrigação passiva universal), que atinge toda a coletividade.

Essa distinção, entretanto, deve ser analisada com cuidado. Isso porque a obrigação passiva universal, consistente no dever de respeitar o direito alheio, não é exclusiva dos direitos reais, haja vista também incidir nos direitos de crédito, a justificar a tutela externa do crédito (PERLINGIERI, 2002, p. 142).

A eficácia erga omnes dos direitos reais deve ser compreendida não como a obrigação passiva universal, mas como a possibilidade de o titular do direito real exercer seu direito em face de quem quer que se interponha entre ele e o aproveitamento da coisa. O direito real, em uma palavra, é dotado de sequela, sendo esta sua nota distintiva em relação ao direito de crédito. A sequela, assim, não significa a imposição à coletividade de um dever geral de abstenção, mas o afastamento de todos aqueles que se antepõem ao regular exercício do direito real (COMPORTI, 1977, p. 155).

Veja-se que a sequela compõe a fisiologia do direito real, e não apenas o momento patológico, ao contrário da oponibilidade ensejadora da tutela externa do crédito. A título ilustrativo, o credor hipotecário que excute a garantia em face do proprietário que comprou o bem do devedor não está a reagir contra a violação da hipoteca (RENTERIA, 2016, p. 61). A venda do bem hipotecado configura ato legítimo do devedor que, por outro lado, mostra-se irrelevante ao credor, na medida em que este pode perseguir o bem e exercer o seu direito em face do terceiro comprador, haja vista o direito de sequela.

A sequela, vale ressaltar, incide independentemente da boa ou má-fé do terceiro. 0 titular do direito real pode impor seu direito contra quem quer que interfira no seu regular 
exercício, esteja ou não de boa-fé. Nessa direção, o parágrafo único do art. 1.247 do Código Civil reconhece a nulidade do registro da venda a non domino de imóvel, podendo o proprietário reivindicar o bem em face do terceiro adquirente de boa ou de má-fé. ${ }^{2} \mathrm{O}$ dispositivo consagra a "prevalência do direito oculto do legítimo proprietário em detrimento do adquirente do imóvel que acreditou na fé pública do registro" (RENTERIA, 2016, p. 64).

Os direitos reais e os pessoais, portanto, se diferenciam pelo diverso regime de oponibilidade, uma vez que apenas os direitos reais são dotados de sequela. O direito real, em razão da sequela, traduz situação jurídica subjetiva provida de eficácia contra terceiros de boa ou má-fé, eficácia esta que se verifica independentemente da violação do direito real (RENTERIA, 2016, p. 64; OLIVA E RENTERIA, 2015, p. 103-136). A tutela externa do crédito, a seu turno, não se aplica em face de terceiro de boa-fé e apenas é deflagrada por ocasião da violação do direito de crédito.

Por força da sequela, os direitos reais, ao contrário dos pessoais, submetem-se aos princípios da taxatividade e da tipicidade (v. item 6, infra). Os vínculos pessoais, a seu turno, podem ser livremente estabelecidos pela autonomia privada, regendo-se pelo princípio da atipicidade (art. 425, Código Civil). ${ }^{3}$

\section{OBRIGAÇÕES PROPTER REM}

\section{Noções gerais}

No âmbito da tradicional classificação estrutural entre direitos reais e pessoais, importa analisar as obrigações propter rem, cuja natureza jurídica suscita dúvidas, uma vez que se configuram quando o titular de uma situação jurídica subjetiva real ou possessória é obrigado, devido a essa condição, a satisfazer determinada prestação: a obrigação está vinculada à coisa (SERPA LOPES, 1966, p. 46).

Os sujeitos da obrigação propter rem não se encontram sempre perfeitamente individualizados, mas são determináveis (CÂNFORA, 1996, p. 8; TRABUCCHI, 1993, p. 490). Os sujeitos ativos e passivos são individualizados mediatamente com referência à titularidade de um direito real ou relação de posse (ABERKANE, 1957, p. 18). O devedor propter rem é o titular

\footnotetext{
${ }^{2}$ Art. 1.247, Código Civil: "Se o teor do registro não exprimir a verdade, poderá o interessado reclamar que se retifique ou anule. Parágrafo único. Cancelado o registro, poderá o proprietário reivindicar o imóvel, independentemente da boa-fé ou do título do terceiro adquirente".

${ }^{3}$ Art. 425, Código Civil: "É lícito às partes estipular contratos atípicos, observadas as normas gerais fixadas neste Código".
} 
do domínio, de um direito real sobre a coisa alheia ou simplesmente o sujeito ativo de uma relação possessória. Não interessam as características pessoais do devedor propter rem, mas a circunstância de ele ser, naquele momento, o titular do direito real ou da situação possessória (ASCENSÃO, 1978, p. 179; NATUCCI, 1988, p. 298; CODEIRO, 1993, p. 367; SCAPEL, 2002, p. 84).

No direito brasileiro, podem-se apontar como exemplos de obrigações propter rem a obrigação do condômino de conservar a coisa comum (art. 1.315 do Código Civil) e a do proprietário de contribuir para as despesas de construção e conservação de tapumes divisórios (art. 1.297 do Código Civil).

No que se refere à natureza jurídica da obrigação propter rem, é possível identificar três entendimentos (CORDEIRO, 1993, p. 368). Há quem defenda possuir eficácia real (ESPÍNOLA, 1944, p. 16; DIEZ-PICAZO, 1996, p. 71; DANTAS, 1972, p. 244); outros entendem tratar-se de espécie obrigacional (AZEVEDO, 2004, p. 314-315; MESSINEO, 1959, p. 51); e, por fim, há os que Ihe atribuem natureza mista (PEREIRA, 2016, p. 40-41; MAIA, 2011, p. 885-886). A dificuldade na qualificação reside na circunstância de a obrigação propter rem, ao mesmo tempo, se associar à titularidade de um direito real ou do exercício da posse, sendo o devedor determinado a partir de sua relação com a coisa, e consubstanciar dever que vincula pessoalmente o sujeito, para cujo cumprimento este responde com todo o seu patrimônio. Sem embargo dessa discussão, o certo é que a obrigação propter rem se caracteriza pela acessoriedade ao direito real do qual surge, do que decorre a determinabilidade do devedor pela sua relação com a coisa, e não por suas características pessoais (SCAPEL, 2002, p. 98-99; NATUCCI, 1988, p. 309).

\section{O problema da sucessão das obrigações propter rem}

Questão controvertida consiste em saber se a obrigação propter rem acompanha o destino do direito real do qual se origina quando nele se opera uma mutação subjetiva (MESQUITA, 2000, p. 312). A dúvida surge quando, verificados os pressupostos que condicionam o nascimento da obrigação propter rem, ocorra um ato translativo do direito real antes do cumprimento desta (MESQUITA, 2000, p. 315; NATUCCI, 1988, p. 319; BALBI, 1950, p. 145). Não há dissenso na doutrina acerca da vinculação do titular de uma situação jurídica real às obrigações propter rem nascidas enquanto perdurar a titularidade. Contudo, uma vez verificado o ato translativo do domínio, diverge-se quanto à responsabilidade pelas obrigações 
propter rem nascidas - mas ainda não cumpridas - antes deste ato, sendo possível identificar três posicionamentos principais.

O primeiro deles sustenta que devem ser consideradas ambulatórias todas as obrigações reais de facere que imponham ao devedor a prática de atos materiais na coisa que constitui o objeto do direito real (MESQUITA, 2000, p. 330-331), ao passo que "todas as demais obrigações propter rem - quase sempre, obrigações de dare - devem considerar-se, em princípio, não ambulatórias", com exceção daquelas cujos pressupostos materiais se encontram objetivados na coisa sobre a qual incide o direito real (MESQUITA, 2000, p. 336-337).

O segundo entendimento, por outro lado, corresponde à ideia de que o titular do direito real só fica vinculado às obrigações propter rem constituídas na vigência do seu direito. Nessa perspectiva, as obrigações propter rem consistiriam em verdadeiras obrigações, servindo a situação subjetiva real somente para determinar a titularidade do sujeito passivo, que, uma vez determinado, permaneceria o mesmo independentemente da mudança da titularidade do direito real. Deste modo, as obrigações reais teriam fonte ambulatória, mas, uma vez constituídas, se autonomizariam e gravariam o patrimônio do titular, regendo-se, a partir daí, pelas regras comuns a qualquer relação obrigacional (VARELA, 2000, p. 195; SCHREIBER E TEPEDINO, 2003, p. 32; SARMENTO FILHO, 1998, p. 9).

A terceira orientação, por outro lado, sustenta que o novo titular da relação jurídica de direito real responde pelas obrigações propter rem nascidas mesmo antes de sua titularidade (CÂNFORA, 1996, p. 10; BALBI, 1950, p. 149-152), ressalvado o direito de regresso. ${ }^{4}$

Observe-se, por oportuno, que o adquirente deve cumprir todas as obrigações propter rem nascidas a partir da sua titularidade, independentemente de eventual anterior descumprimento por parte do alienante. A título ilustrativo, o adquirente não pode se escusar de construir tapumes divisórios (art. 1.927, Código Civil) sob alegação de que tal obrigação jamais fora cumprida pelo alienante. Por outro lado, o que se questiona é se os efeitos do inadimplemento do antecessor - e. g. danos decorrentes da não construção do tapume - se

\footnotetext{
${ }^{4}$ TJRS, Ap. Cív. 70010109957, 20a CC, Rel. Des. José Aquino Flores De Camargo, julg. 29.12.2004; TJRS, 20a CC, Ap. Cív. 70009945767, Rel. Des. Heleno Tregnago Saraiva, julg. 23.11.2004; TJMG, Ap. Cív. 1.0701.03.039245-3/001(1), 2a CC, Rel. Des. Brandão Teixeira, julg. 23.11.2004; TJDFT, Ap. Cív. 20030110766765, 1a T Cível, Rel. Des. João Egmont Leôncio Lopes, julg. 21.6.2004; TJRS, Ap. Cív. 70071916340, 18a CC, Rel. Des. João Moreno Pomar, julg. 12.12.2016; TJRS, Ap. Cív. 70066187139, 20aa CC, Rel. Des. Dilso Domingos Pereira, julg. 16.9.2015; TJMG, Ap. Cív. 0020641-79.2015.8.13.0637 (1), 16a CC, Rel. Des. Wagner Wilson, julg. 22.6.2016 e TJDFT, Ap. Cív. 20150111248015, 1a T Cível, Rel. Des. Teófilo Caetano, julg. 28.9.2016.
} 
transmitem ao sucessor ou se este apenas responde pelo seu próprio atraso, se houver, na edificação da divisória.

Ao propósito, importa analisar se o Código Civil dispensou algum tratamento à questão da sucessão das obrigações propter rem. O art. 502 do Código Civil estabelece que "O vendedor, salvo convenção em contrário, responde por todos os débitos que gravem a coisa até o momento da tradição". Faz-se necessário averiguar se a expressão que gravem a coisa foi empregada pelo legislador em sentido amplo, de modo a abarcar as obrigações propter rem e os ônus reais, ou se abrange apenas um deles.

Conforme será exposto no item 5, infra, o ônus real corresponde a um dever jurídico que, uma vez nascido, acompanha a coisa em suas mutações subjetivas. Por esta razão, a melhor interpretação é a que exclui do alcance do art. 502 os ônus reais - a despeito da expressão que gravem a coisa - uma vez que estes acompanham necessariamente a coisa na mudança de titularidade, cabendo ao novo adquirente arcar com estes deveres.

Ao se considerar que o preceito quis se referir apenas às obrigações propter rem, podese inferir que o legislador de 2002 adotou como disciplina geral aplicável às obrigações reais a que impõe ao titular da situação subjetiva real a responsabilidade apenas pelos débitos nascidos na vigência de seu direito, cabendo ao alienante arcar com as dívidas surgidas antes da alienação. Sendo assim, o alienante não perde sua condição de devedor e tampouco o adquirente se torna responsável pelas obrigações propter rem descumpridas pelo antecessor.

Por outras palavras, o Código Civil de 2002, em seu art. 502, estipulou, como regra geral, que as obrigações reais, uma vez constituídas, se autonomizam e passam a gravar o patrimônio do titular da situação jurídica subjetiva real, que se torna responsável pelo adimplemento dos débitos propter rem. Assim, não obstante ocorra posterior mutação subjetiva do direito real, o titular passivo da obrigação propter rem não se altera.

Essa consequência se aplica não apenas à obrigação de dar que se renova periodicamente, mas igualmente à prestação de fazer. Sendo a obrigação propter rem de fazer, esta obriga imediatamente o adquirente a executá-la, embora o alienante permaneça devedor único no que tange aos efeitos do não cumprimento desta obrigação no período em que foi titular de direito real ou possuidor da coisa.

O direito brasileiro, portanto, se filiou à concepção segundo a qual a obrigação propter rem tem fonte ambulatória, mas, uma vez nascida, desprende-se da coisa e passa a gravar o patrimônio do titular desta, acompanhando-o mesmo em caso de posterior alienação do bem. 


\section{Natureza jurídica das taxas condominiais. Responsabilidade do adquirente pelos encargos condominiais anteriores à alienação da unidade imobiliária .}

Por encargos condominiais entendem-se as despesas atribuídas ao condômino relacionadas:

a. à manutenção da coisa comum, imprescindíveis à viabilidade e à existência do condomínio (PEREIRA, 2002, p. 142);

b. ao ressarcimento aos demais condôminos pelos danos ocasionados com a realização de obras e reparações na unidade autônoma (PEREIRA, 2002, p. 147-148); e

c. ao ressarcimento de terceiros por força de eventual imputação de responsabilidade civil do condomínio (LOPES, 2003, p. 91). Os encargos condominiais refletem, principalmente, as despesas efetuadas para a conservação da coisa comum, de modo que o adimplemento dos condôminos no pagamento de sua quota para fazer frente a estas despesas é condição essencial à própria existência do condomínio.

Pode acontecer, entretanto, que determinado condômino não esteja pagando devidamente as taxas condominiais, ou que tenha realizado obras que danificaram a parte comum sem providenciar a reparação dos danos, ou, ainda, que deva contribuir para o pagamento de indenização devida pelo condomínio, mas, antes de cumprir tal obrigação, aliene sua unidade autônoma. Nestas hipóteses, seria possível a responsabilização do adquirente por débitos junto ao condomínio nascidos antes de sua aquisição?

O parágrafo único do artigo 4으 da Lei 4.591, de 16 de dezembro de 1964, dispunha, em sua primeira redação, que "o adquirente de uma unidade responde pelos débitos do alienante, em relação ao condomínio, inclusive multas". Com base em tal preceito legal, o entendimento predominante consistia na responsabilização do adquirente por tais débitos (PEREIRA, 2002, p. 189).

Posteriormente, a Lei 7.182, de 27 de março de 1984, alterou a redação do parágrafo único do artigo 4o da Lei 4.591/64 para: "A alienação ou transferência de direitos de que trata este artigo dependerá de prova de quitação das obrigações do alienante para com o respectivo condomínio". A Lei 7.433, de 18 de dezembro de 1985, em seu art. 2ํ, § 2ํ, dispôs que faz prova de quitação a declaração feita pelo alienante ou seu procurador, sob as penas da lei, a ser expressamente consignada nos instrumentos de alienação ou transferência de direitos. Destaque-se que a exigência, para alienação de unidade autônoma, de quitação das obrigações 
condominiais pendentes, não teve o condão de modificar o entendimento de que o adquirente deve responder pelos débitos do alienante junto ao condomínio. ${ }^{5}$

Sobre o tema, o Código Civil de 2002 trouxe a seguinte regra, em seu artigo 1.345: "O adquirente de unidade responde pelos débitos do alienante, em relação ao condomínio, inclusive multa e juros moratórios". João Batista Lopes afirma, na esteira do posicionamento prevalente, que a regra contida no artigo 1.345 é indispensável para a própria subsistência do condomínio, "cuja saúde financeira não pode ficar à mercê das mudanças na titularidade dominial" (LOPES, 2003, p. 98). ${ }^{6}$ Mas será que tal solução é condizente com a natureza jurídica atribuída aos encargos condominiais?

Às despesas condominiais tem sido atribuída, majoritariamente, natureza jurídica de obrigação propter rem (MIRANDA, 2012, p. 162), uma vez que o nascimento de tal dever jurídico "não decorre da manifestação de vontade do devedor, (...) mas do simples fato de o sujeito passivo da obrigação apresentar a qualidade de titular de um direito real" (SARMENTO FILHO, 1998, p. 9). Com efeito, na obrigação propter rem o devedor é identificado mediatamente, em virtude de sua titularidade em relação a uma situação jurídica subjetiva real.

Conforme abordado no item 3.2, discute-se se no caso de transmissão do direito real, a título singular, transferem-se, igualmente, os débitos propter rem já nascidos - e ainda não cumpridos - ao tempo da celebração do negócio translativo de domínio. Verificou-se que há três principais entendimentos a este respeito, tendo o Código Civil, no art. 502, se filiado àqueles que sustentam que o titular de uma situação jurídica subjetiva real só é responsável pelos débitos propter rem que se constituírem no período de sua titularidade. Ou seja, as obrigações reais têm fonte ambulatória, mas, uma vez nascidas, gravam o patrimônio do titular

5 “(...) O aspecto eminentemente prático do novo texto não descaracteriza a natureza jurídica da obrigação do condômino. Ao contrário, reforça-se na medida em que habilita o condomínio a opor-se à transferência do domínio da unidade antes de adimplidas as obrigações da unidade para com o condomínio, em virtude do que se pode afirmar que a obrigação ambulat cum domino. Como se vê, é irrelevante a pessoa do titular da propriedade da unidade na relação condomínio-condômino, pois os direitos e obrigações daí decorrentes dizem com a circunstância da existência da pluralidade de titulares do domínio de um mesmo bem. Em outras palavras, se estabelecem exclusivamente em razão da coisa havida em co-propriedade, e não em função da pessoa titular da quota-parte. Em consequência, repelese $o$ argumento de que a aquisição da unidade diretamente de um dos próprios exequentes excluiria a responsabilidade pelo débito ora cobrado. Se para a existência da obrigação de arcar com as despesas comuns é irrelevante a pessoa do titular do domínio e, sim, o fato de existir o condomínio, com maior razão é inócuo perquirir a origem da aquisição (...)" (STJ, REsp. 1654, 4ạ T., Rel. Min. Sálvio de Figueiredo Teixeira, julg. 11.12.1989).

${ }^{6}$ Neste sentido, v. tb. STJ, REsp. 547638, 4a T., Rel. Min. Aldir Passarinho Júnior, julg. 10.8.2004; STJ, REsp. 194481, 4a T., Rel. Min. Ruy Rosado de Aguiar, julg. 4.2.1999; STJ, REsp 671941, Rel. Min. Aldir Passarinho Junior, 4a T, julg. 28.3.2006; TJRJ, 4a T, Rel. Min. Aldir Passarinho Junior, julg. 28.3.2006 e STJ, AgRg no REsp 1370088 3a T, Rel. Min. Paulo De Tarso Sanseverino, julg. 23.6.2015. 
da situação jurídica real, passando, a partir daí, a seguir as regras próprias de qualquer obrigação (SCHREIBER E TEPEDINO, 2003, p. 32). Não obstante ocorra posterior mutação subjetiva do direito real, o titular passivo da obrigação propter rem descumprida não é alterado.

Por outro lado, o art. 1.345 do Código Civil preceitua que o adquirente de uma unidade autônoma responde pelos débitos do alienante, em relação ao condomínio, inclusive multa e juros moratórios. Importa indagar, diante disto, qual a interpretação que deve ser conferida ao preceito à luz do sistema estabelecido pelo Código Civil de 2002.

A despeito da orientação contida no art. 502 do Código Civil, o art. 1.345 do mesmo diploma, ponderando os interesses em jogo, decidiu privilegiar o condomínio em detrimento do adquirente, determinando a responsabilidade deste em relação aos encargos condominiais e multa nascidos antes da aquisição do direito real, preservando, com isso, a tradição legislativa em matéria de condomínio edilício. O direito de regresso assegurado ao adquirente, por outro lado, evidencia que o débito permanece sendo do alienante, que continua devedor, tornandose o adquirente, a rigor, garantidor da dívida e, por isso, sua obrigação é acessória à do alienante. Tal solução, pontual e restrita, não descaracteriza a regra geral, adotada pelo Código Civil, de que as obrigações propter rem, uma vez nascidas, vinculam pessoalmente o titular do direito real, que deve satisfazer as obrigações reais constituídas na vigência de seu direito.

Ao se interpretar o art. 1.345 em conjunto com o art. 502, ambos do Código Civil, percebe-se que a transmissão, a título singular, do direito real, não tem o condão de alterar o polo passivo da relação obrigacional. No condomínio edilício, em virtude dos interesses envolvidos, optou o legislador por tornar o adquirente garantidor do pagamento dos débitos do alienante. Vale dizer, o legislador criou expediente para proteger o condomínio, possibilitando que a ação de cobrança de encargos condominiais seja proposta diretamente em face do adquirente, já que este possui, ao menos, um bem para ser executado, qual seja, a unidade autônoma. Todavia, tal possibilidade conferida ao condomínio não altera o devedor da obrigação propter rem, que continua sendo o alienante. Dessa forma, o alienante permanece como devedor das obrigações reais nascidas na vigência de sua titularidade e, por esta razão, não há porque se excluir a possibilidade de o condomínio cobrar seu crédito diretamente do alienante. 


\section{Natureza jurídica das obrigações ambientais instituídas pelo Código Florestal.}

O Código Florestal (Lei 12.651/2012), em seu art. $2^{\circ}, \S 2^{\circ}$, estabelece que "as obrigações previstas nesta Lei têm natureza real e são transmitidas ao sucessor, de qualquer natureza, no caso de transferência de domínio ou posse do imóvel rural”. As obrigações ambientais constantes no Código Florestal aderem à coisa e consubstanciam obrigações propter rem. Disso decorre que os deveres previstos em lei não incidem sobre o proprietário ou possuidor pessoalmente considerados, mas sim sobre todos aqueles que vierem a ser proprietários ou possuidores, uma vez que as imposições relativas ao meio ambiente vinculam o exercício da propriedade ou da posse por quem quer que seja, haja vista sua natureza propter rem. ${ }^{7}$

As obrigações ambientais, assim, por aderirem à coisa, transmitem-se ao novo proprietário ou possuidor, sujeito passivo desses deveres em virtude de sua relação com a coisa. O alienante, todavia, continua responsável pelas obrigações propter rem nascidas na vigência da sua titularidade e, conseguintemente, pela reparação dos eventuais danos decorrentes do seu descumprimento.

Com efeito, consoante se verificou no item 3.2, supra, as dívidas propter rem, uma vez nascidas, passam a vincular pessoalmente o devedor, desprendendo-se da coisa. Desse modo, o descumprimento da obrigação propter rem imputável ao alienante não obriga o adquirente da coisa a reparar os danos daí decorrentes.

Ao propósito, cumpre distinguir dois componentes do dever de reparação. De uma parte, há a restauração ambiental da coisa degradada, a qual coincide com a obrigação, imposta indistintamente a todos os proprietários, dada sua natureza real, de adequação do imóvel às normas ambientais. ${ }^{8}$ Cuida-se, a rigor, de duas obrigações distintas, mas que, na prática,

\footnotetext{
7 "De acordo com a jurisprudência do STJ, a obrigação de demarcar, averbar e restaurar a área de reserva legal constitui-se uma obrigação propter rem, que se transfere automaticamente ao adquirente ou ao possuidor do imóvel rural. Esse dever jurídico independe da existência de floresta ou outras formas de vegetação nativa na gleba, cumprindo-Ihes, caso necessário, a adoção das providências essenciais à restauração ou à recuperação das mesmas, a fim de readequar-se aos limites percentuais previstos na lei de regência" (STJ, REsp 1276114/MG, 2ª T., Rel. Min. Og Fernandes, julg. 4.10.2016).

8 "As obrigações ambientais ostentam caráter propter rem, isto é, são de natureza ambulante, ao aderirem ao bem, e não a seu eventual titular. Daí a irrelevância da identidade do dono - ontem, hoje ou amanhã -, exceto para fins de imposição de sanção administrativa e penal. 'Ao adquirir a área, o novo proprietário assume o ônus de manter a preservação, tornando-se responsável pela reposição, mesmo que não tenha contribuído para o desmatamento' (STJ, REsp 926.750/MG, 2a T, Rel. Min. Castro Meira, julg. 20.9.2007. No mesmo sentido, STJ, REsp 343.741/PR, 2a $\underline{a}$ T, Rel. Min. Franciulli Netto, julg. 4.2.2002; REsp 264.173/PR, 1a T, Rel. Min. José Delgado, julg. 15.2.2001; REsp 282.781/PR, 2a T, Rel. Min. Eliana Calmon, julg. 16.4.2002)" (STJ, EREsp 218.781/PR, 1a S., Rel. Min. Herman Benjamin, julg. 9.12.2009).
} 
acabam sendo tratadas como uma só, a ponto de se afirmar que a obrigação de reparar o dano ambiental tem natureza propter rem. ${ }^{9}$

De outra parte, tem-se os demais efeitos da reparação, entre os quais se incluem a indenização de terceiros eventualmente prejudicados pelo dano ambiental, a qual não encontra correspondência em nenhuma obrigação proter rem prevista no Código Florestal. Desse modo, como ocorre no inadimplemento de qualquer obrigação proter rem, tal dever de indenizar, decorrente do descumprimento da obrigação real imputável ao alienante, não vincula o adquirente da coisa, que, por isso, não sucede nesse dever.

Em síntese, consoante se verificou, no direito brasileiro a obrigação propter rem vincula o adquirente a partir do momento em que ele se torna titular ou possuidor da coisa, não respondendo pelas violações efetuadas pelo alienante. Por outras palavras, as obrigações propter rem são ambulatórias e aderem à coisa, mas sua violação obriga pessoalmente o transgressor, não permanecendo na coisa o dever de reparação, que não se transmite ao adquirente. Este, a seu turno, tem o dever, a partir do momento em que adquire o bem, de adequá-lo imediatamente aos preceitos ambientais, sem que seja responsável pelos danos decorrentes da violação pregressa do antigo titular.

\section{OBRIGAÇÕES COM EFICÁCIA REAL.}

As obrigações propter rem não se confundem com as chamadas obrigações com eficácia real. Estas nascem do acordo de vontades - ao contrário das obrigações reais, cuja fonte está relacionada ao regime de uma situação jurídica subjetiva real ou possessória - mas o legislador, ponderando os interesses envolvidos na relação jurídica, estabelece que, mediante o preenchimento de certas condições, a obrigação será dotada de sequela, constituindo, assim, tecnicamente, direito real.

Exemplo de obrigação com eficácia real - que, insista-se, consubstancia, a rigor, direito real (RENTERIA, 2016, p. 59) - consiste no contrato de locação registrado e com cláusula de vigência, conforme preceitua o art. 576 do Código Civil ${ }^{10}$ e, no âmbito da locação de imóveis

\footnotetext{
9 "O STJ possui entendimento pacífico de que a responsabilidade civil pela reparação dos danos ambientais adere à propriedade, como obrigação propter rem, sendo possível cobrar também do atual proprietário condutas derivadas de danos provocados pelos proprietários antigos" (STJ, REsp 1622512/RJ, 2a T., Rel. Min. Herman Benjamin, julg. 22.9.2016). V. tb. STJ, REsp 1454281/MG, 2a T., Rel. Min. Herman Benjamin, julg. 16.8.2016; STJ, AgRg nos EDcl no REsp 1203101/SP, 1a T., Rel. Ministro Hamilton Carvalhido, julg. 8.2.2011.

${ }^{10}$ Art. 576, Código Civil: "Se a coisa for alienada durante a locação, o adquirente não ficará obrigado a respeitar o contrato, se nele não for consignada a cláusula da sua vigência no caso de alienação, e não
} 
urbanos, o art. $8^{\circ}$ da Lei 8.245/1991. ${ }^{11}$ Outro exemplo eloquente de relação obrigacional erigida a direito real tem-se com o direito real do promitente comprador, previsto nos arts. $1.417 \mathrm{e}$ 1.418 do Código Civil. ${ }^{12}$ Aludidos exemplos corroboram que a sequela consubstancia a nota característica dos direitos reais e que o vínculo obrigacional pode se tornar direito real por opção legislativa.

Portanto, a obrigação terá eficácia real e será reputada direito real quando, embora se originando e se regendo pelas normas aplicáveis a qualquer outra espécie obrigacional, for dotada de sequela, desde que preenchidos determinados requisitos previstos em lei. As circunstâncias em que a relação obrigacional pode ter eficácia real se encontram estabelecidas na legislação, a qual traz os pressupostos indispensáveis à oponibilidade do vínculo obrigacional mediante atribuição de tutela real. ${ }^{13}$

\section{ÔNUS REAIS}

Vale distinguir, ainda, as obrigações propter rem dos ônus reais, os quais, embora se assemelhem às obrigações propter rem (TRABUCCHI, 1993, p. 491), com elas não se confundem. Os tribunais mostram-se vacilantes na delimitação dos conceitos de ônus real e obrigação propter rem, os quais, não raro, são tidos como sinônimos. ${ }^{14}$

constar de registro. $\S 1^{\circ} \mathrm{O}$ registro a que se refere este artigo será o de Títulos e Documentos do domicílio do locador, quando a coisa for móvel; e será o Registro de Imóveis da respectiva circunscrição, quando imóvel. $\S 2^{\circ} \mathrm{Em}$ se tratando de imóvel, e ainda no caso em que o locador não esteja obrigado a respeitar o contrato, não poderá ele despedir o locatário, senão observado o prazo de noventa dias após a notificação".

${ }^{11}$ Art. 80, Lei 8.245/1991: "Se o imóvel for alienado durante a locação, o adquirente poderá denunciar o contrato, com o prazo de noventa dias para a desocupação, salvo se a locação for por tempo determinado e o contrato contiver cláusula de vigência em caso de alienação e estiver averbado junto à matrícula do imóvel.

§ 10 Idêntico direito terá o promissário comprador e o promissário cessionário, em caráter irrevogável, com imissão na posse do imóvel e título registrado junto à matrícula do mesmo.

$\S 2$ 2o A denúncia deverá ser exercitada no prazo de noventa dias contados do registro da venda ou do compromisso, presumindo - se, após esse prazo, a concordância na manutenção da locação".

12 Art. 1.417, Código Civil: "Mediante promessa de compra e venda, em que se não pactuou arrependimento, celebrada por instrumento público ou particular, e registrada no Cartório de Registro de Imóveis, adquire o promitente comprador direito real à aquisição do imóvel". Art. 1.418, Código Civil: "O promitente comprador, titular de direito real, pode exigir do promitente vendedor, ou de terceiros, a quem os direitos deste forem cedidos, a outorga da escritura definitiva de compra e venda, conforme o disposto no instrumento preliminar; e, se houver recusa, requerer ao juiz a adjudicação do imóvel".

${ }^{13}$ A distinção entre obrigação com eficácia real e direitos reais parte do pressuposto de que o direito real se caracteriza pelo poder imediato sobre a coisa. Contudo, como se verificou no item 2, supra, deste artigo, a nota distintiva dos direitos reais reside na sequela.

14 “(...) O entendimento desta Corte também é tranquilo no sentido de que os encargos de condomínio configuram modalidade de ônus real, devendo o adquirente do imóvel responder por eventual débito 
Os ônus reais consistem em deveres ambulatórios que gravam a coisa e dela não se desprendem, não gerando obrigações autônomas. Recaem sobre a coisa como um peso (um ônus) (SCHREIBER E TEPEDINO, 2003, p. 32) e com tal intensidade que há quem afirme que, nos ônus reais, quem deve é a coisa (VARELA, 2000, p. 196; TRABUCCHI, 1993, p. 452-453 e 491). Para a satisfação da obrigação propter rem o devedor responde com todo o seu patrimônio, ao passo que no ônus real a satisfação do débito se restringe aos limites da coisa onerada (TRABUCCHI, 1993, p. 453; VARELA, 2000, p. 195-196).

No direito brasileiro, o legislador refere-se a ônus real para aludir aos deveres contrapostos aos direitos reais sobre a coisa alheia e aos tributos que incidem sobre a coisa, cujo fato gerador seja a titularidade de um direito real. ${ }^{15}$ Dessa forma, os ônus reais constituem espécie peculiar de dever contraposto às prerrogativas asseguradas aos titulares dos direitos reais, de molde a gravar o bem sobre o qual se exerce a titularidade, limitando, assim, a extensão do aproveitamento econômico (a senhoria).

Em se tratando de ônus real, a doutrina é pacífica no sentido de considerá-lo ambulatório, de modo que o adquirente do direito real é o responsável pelo cumprimento dos ônus reais ainda que constituídos anteriormente à sua titularidade. Tal responsabilidade, todavia, limita-se às forças do objeto do direito real, a menos que haja responsabilidade pessoal do adquirente, vinculando todo o seu patrimônio à satisfação da dívida que onera a coisa.

A hipoteca, por exemplo, grava o bem, que pode ser agredido pelo credor em caso de inadimplemento independentemente de quem seja o titular do bem no momento da execução da garantia (CORDEIRO, 1993, p. 755). O adquirente do bem hipotecado não responde com o restante de seu patrimônio pelo eventual remanescente da dívida, uma vez que o credor tem, na relação jurídica acessória de hipoteca, pretensão executória circunscrita ao bem que se encontra gravado. Trata-se de ônus real, em que somente o valor da coisa responde pela dívida. Por outro lado, se o proprietário do bem, concomitantemente, por força de disposição legal ou

existente. Trata-se de obrigação propter rem. Precedentes. 3. Agravo regimental improvido" (STJ, AgRg no AG 305718/RS, 3a T., Rel. Min. Carlos Alberto Menezes Direito, julg. 29.8.2000, grifou-se). V. tb. STJ, REsp. 109638/RS, 3a T, Rel. Min. Waldemar Zveiter, julg. 12.5.1997; STJ, REsp. 6123/RJ, 3a T, Rel. Min. Waldemar Zveiter, julg. 11.12.1990; STJ, AgRg no Ag 667222/SP, 3a T, Rel. Min. Carlos Alberto Menezes Direito, julg. 17.11.2005. Cf., ainda, TJRJ, Ap. Cível 0328426-87.2013.8.19.0001, 10a CC, Rel. Des. Pedro Saraiva De Andrade Lemos, julg. 14.9.2016; TJMG, EAC 1.0024.13.101443-3/002, 14a CC, Rel. Des. Estevão Lucchesi, julg. 9.6.2016; e TJRS, Ag 70054040761, 21ạ CC, Rel. Des. Genaro José Baroni Borges, julg. 4.9.2013.

${ }^{15}$ Confiram-se os seguintes dispositivos do Código Civil: art. 978; art. 1.105, parágrafo único; art. 1.276, § 2o; art. 1.315; art. 1.474; art. 1.488; art. 1.647, I; art. 1.687; art. 1.691. Vejam-se, ainda, os arts. 279 e 292 da Lei 6.015, de 31 de dezembro de 1973. 
contratual, possuir responsabilidade pessoal pelo adimplemento da obrigação, o credor poderá adentrar e excutir o seu patrimônio para satisfazer seu crédito. Nesta hipótese, há vínculo pessoal que confere título jurídico para que o credor ingresse no patrimônio do devedor com vistas à satisfação do crédito.

\section{OS PRINCÍPIOS DA TAXATIVIDADE E DA TIPICIDADE E AS OBRIGAÇÕES PROPTER REM.}

O princípio da taxatividade diz com a exclusiva competência do legislador para a criação de direitos reais, aos quais, por sua vez, atribui conteúdo típico, daí decorrendo como segundo princípio, corolário do primeiro, o da tipicidade dos direitos reais (TEPEDINO, 1993, p. 82; TEPEDINO, 2006, p. 287-288; ASCENSÃO, 1968, p. 104-105). Enquanto a taxatividade concerne à fonte do direito real, a tipicidade se refere à modalidade de seu exercício. Ao contrário dos direitos de crédito - aos quais se aplica o princípio da liberdade da autonomia privada para a sua criação - os direitos reais, por serem dotados de sequela, devem ter seus contornos estipulados em lei (TEPEDINO, 2006, p. 287; GONDINHO, 2001, p. 153-154; TEIXEIRA DE FREITAS, 1910, p. 25-26; MIRANDA, 2012, p. 133-134).

O sistema do numerus clausus constitui-se em orientação relacionada à política legislativa, não se configurando elemento ontologicamente vinculado à teoria dos direitos reais (TEPEDINO, 2006, p. 289; PERLINGIERI, 2002, p. 202). Destaque-se, ainda, que, embora os direitos reais estejam submetidos aos princípios da taxatividade e da tipicidade, a autonomia privada encontra espaço, no âmbito dos poderes conferidos aos respectivos titulares, para moldar a situação jurídica real aos seus interesses. Com efeito, ao lado das regras imperativas, que definem a existência e o conteúdo de cada tipo real, coexistem preceitos dispositivos, atribuídos à autonomia privada, que permitem aos particulares maior adequação da situação jurídica real aos seus interesses (ASCENSÃO, 1978, p. 304; OLIVA E RENTERIA, 2016, p. 7-10; TEPEDINO, 1993, p. 83). Por esta razão, deve-se analisar não apenas o respeito aos princípios da taxatividade e da tipicidade, mas também se as cláusulas apostas pela atividade econômica privada nos tipos reais são merecedoras de tutela (TEPEDINO, 2006, p. 291).

Nesta seara, surge a imbricada questão de se saber se os particulares podem criar livremente as obrigações reais ou se, do mesmo modo que os direitos reais, só são admitidas aquelas previstas em lei. Mostra-se consolidado o entendimento de que as obrigações reais devem ter conteúdo típico e fonte taxativa (GONDINHO, 2001, p. 123). Argumenta-se, neste 
sentido, que, em razão da oponibilidade das obrigações propter rem, não é consentido à autonomia privada criar, livremente, novas espécies de obrigações capazes de vincular todos os que venham a ser titulares da situação jurídica real ou possessória (NATUCCI, 1988, p. 320-322). Ou seja, alega-se que a autonomia privada não pode impor uma obrigação a todo aquele que, no futuro, venha a ser titular de determinada situação jurídica subjetiva real ou possessória (MESQUITA, 2000, p. 284-288).

Por oportuno, sublinhe-se que, corolário da oponibilidade erga omnes do direito de sequela é a publicidade dos direitos reais. De fato, se todos estão sujeitos aos efeitos da relação real, independentemente de terem participado ou não de sua constituição, entende-se a exigência da publicidade na constituição e transmissão dos direitos reais (ARAÚJO, 2005, p. 113). Poder-se-ia entender que a publicidade conferida pelo registro no Registro de Imóveis supriria a necessidade de aplicação dos princípios da taxatividade e tipicidade, pois o futuro adquirente do direito real teria condições de saber das obrigações a que estaria vinculado caso viesse a ser o titular da situação jurídica real. Entretanto, a publicidade não prescinde, no sistema brasileiro, do princípio da taxatividade. Não é possível que a autonomia privada estipule obrigações propter rem ao seu alvedrio, tendo o único cuidado de registrá-las. Tal importaria desarrazoada limitação no direito de propriedade de futuros adquirentes, desvinculados do contexto que levou à criação da obrigação real.

Ressalte-se, contudo, que, no que se refere aos deveres impostos aos condôminos por força da convenção do condomínio, a aplicação dos princípios da taxatividade e da tipicidade sofre mitigação (GONDINHO, 2001, p. 124-125). Com efeito, o caput do art. 1.334 dispõe que "além das cláusulas referidas no art. 1.332 e das que os interessados houverem por bem estipular, a convenção determinará: (...)". Observe-se que as obrigações contidas na convenção de condomínio são oponíveis a todos os atuais e futuros condôminos (NASCIMENTO, 2003, p. 143), sujeitos passivos de tais obrigações pela simples razão de serem titulares de uma situação jurídica real. Daí o caráter propter rem dessas obrigações. Ora, se o art. 1.334 do Código Civil confere liberdade para que a convenção de condomínio estipule as cláusulas que houver por bem, pode-se entender que abriu espaço para a criação de novas obrigações propter rem pela autonomia privada no âmbito da gestão da vida condominial.

É imprescindível, por isso mesmo, que tais cláusulas sejam submetidas a juízo de valor, a fim de verificar se são merecedoras de tutela (PERLINGIERI, 2002, p. 92-93). Não é possível, com efeito, a estipulação de cláusulas arbitrárias, que vinculem desarrazoadamente todos os 
atuais e futuros titulares de direitos reais sobre as unidades autônomas. A autonomia privada carece de controles, principalmente se tem o poder de sujeitar futuros consortes.

Do exposto, e na esteira da doutrina majoritária, vê-se que as obrigações reais devem se sujeitar, do mesmo modo que os direitos reais de que surgem, e pelas mesmas razões, aos princípios da taxatividade e da tipicidade. Todavia, no âmbito do condomínio horizontal, o codificador mitigou tais princípios ao permitir que os consortes estipulem, na convenção de condomínio, as obrigações que entendam convenientes. Tal liberdade, principalmente por vincular futuros consortes, submete-se a rigoroso controle valorativo, averiguando-se, em concreto, seu merecimento de tutela.

\section{CONCLUSÃO}

As obrigações propter rem se configuram quando o titular de uma situação jurídica subjetiva real ou possessória é obrigado, devido a essa condição, a satisfazer determinada prestação: a obrigação está vinculada à coisa. Os sujeitos da obrigação propter rem são individualizados mediatamente com referência à titularidade de um direito real ou relação de posse.

A principal controvérsia atinente às obrigações propter rem diz com sua sucessão quando há a transferência da coisa antes do seu cumprimento. Não se discute que o adquirente deve observar todas as obrigações reais nascidas a partir da sua titularidade. A dúvida é se ele sucede a dívida do seu antecessor, em face de quem teria direito de regresso.

Consoante se verificou, no direito brasileiro a obrigação propter rem vincula o adquirente a partir do momento em que ele se torna titular de direito real ou possuidor da coisa, por força do art. 502 do Código Civil. Não responde o adquirente, dessa maneira, pelas violações efetuadas pelo antigo titular ou possuidor. As obrigações propter rem são ambulatórias e aderem à coisa, mas a violação destas obriga pessoalmente o transgressor, não permanecendo na coisa e, por isso, não se transmitindo ao adquirente.

Note-se que o adquirente deve cumprir todas as obrigações propter rem que incidam sobre a coisa nascidas a partir de quando dela se tornou titular ou possuidor, independentemente de eventual anterior descumprimento por parte do alienante. A título ilustrativo, o adquirente não pode se escusar de construir tapumes divisórios (art. 1.927, Código Civil) sob alegação de que tal obrigação jamais fora cumprida pelo alienante. Por outro lado, os efeitos do inadimplemento do antecessor - e. g. danos decorrentes da não construção do 
tapume - não se transmite ao sucessor, que apenas responde pelo seu próprio atraso, se houver, na edificação da divisória.

No que tange ao condomínio edilício, contudo, o legislador, no art. 1.345 do Código Civil, com o intuito de proteger a coletividade dos condôminos e garantir a preservação da coisa comum, tornou o adquirente responsável pelos débitos pretéritos a cargo do alienante, sem que este, por outro lado, perca sua condição de devedor. $\mathrm{O}$ adquirente, dessa forma, adquire a condição de garantidor e, caso pague os débitos do alienante, pode pleitear ressarcimento em ação de regresso.

Destaque-se, ainda, que no âmbito da proteção ao meio ambiente promovida pelo Código Florestal, as obrigações nele estabelecidas são reais e, conseguintemente, aderem à coisa. Embora eventual transgressão das normas ambientais pelo antigo proprietário não vincule o adquirente, este deve, a partir do momento em que se tornou titular, observar rigorosamente os preceitos ambientais e adequar o imóvel a todos eles. Nesse sentido, há convergência entre o dever imposto ao antigo proprietário de reparar o dano e a obrigação ambulatória imposta ao adquirente de adequar sua propriedade, rigorosa e imediatamente, às normas ambientais. O dever de reparar a cargo do alienante é mais amplo e abrange não apenas a reconstrução do ecossistema, como também a reparação integral dos efeitos deletérios, inclusive para terceiros, da degradação do meio ambiente. Esse dever de reparação obriga pessoalmente o transgressor, não permanecendo na coisa e não se transmitindo ao adquirente. Este, a seu turno, tem o dever, a partir do momento em que adquire o bem, de adequá-lo aos preceitos ambientais, sem que seja responsável pelos danos decorrentes da violação pregressa do antigo titular.

Importa sublinhar, além disso, que as obrigações propter rem não se confundem com as chamadas obrigações com eficácia real. Estas, em primeiro lugar, nascem do acordo de vontades, ao contrário das obrigações propter rem, cuja fonte está relacionada ao regime de uma situação jurídica subjetiva real ou possessória. Além disso, o legislador, uma vez preenchidas certas condições, atribui sequela às chamadas obrigações com eficácia real, que passam a constituir, assim, tecnicamente, direito real. Portanto, a obrigação terá eficácia real e será considerada direito real quando, embora se originando e regendo-se pelas normas aplicáveis a qualquer outra espécie obrigacional, é dotada de sequela, desde que observados os requisitos previstos em lei.

As obrigações propter rem também se diferenciam dos ônus reais, que constituem espécie peculiar de dever contraposto às prerrogativas asseguradas aos titulares dos direitos 
reais sobre a coisa alheia. Para a satisfação de uma obrigação propter rem, o devedor responde com todo o seu patrimônio, ao passo que no ônus real o pagamento do débito se restringe aos limites da coisa onerada. Ao contrário das obrigações propter rem, o adquirente se vincula ao cumprimento dos ônus reais constituídos anteriormente à sua titularidade. Tal responsabilidade, todavia, limita-se às forças do objeto do direito real, a menos que haja responsabilidade pessoal do adquirente, vinculando todo o seu patrimônio à satisfação da dívida que onera a coisa.

Ademais, mostra-se consolidado o entendimento de que as obrigações reais devem ter conteúdo típico e fonte taxativa. Ressalte-se, contudo, que, no que se refere aos deveres impostos aos condôminos por força da convenção do condomínio, a aplicação dos princípios da taxatividade e da tipicidade sofre mitigação, em virtude do disposto no caput do art. 1.334, que autoriza que os condôminos, na convenção de condomínio, fixem as obrigações que entenderem oportunas para a gestão da vida condominial. É imprescindível, por isso mesmo, que tais cláusulas sejam submetidas a juízo de valor, a fim de verificar se são merecedoras de tutela.

Portanto, o regime jurídico das obrigações propter rem no direito brasileiro caracterizase pela sua vinculação ao estatuto de um direito real ou relação possessória, mas, uma vez nascidas, passam a obrigar pessoalmente o titular ou possuidor, não havendo transmissão, ao adquirente, dos efeitos da violação perpetrada pelo alienante. Essa regra não é absoluta, como se observou, para o caso do condomínio edilício, a teor do art. 1.345 do Código Civil, que também flexibiliza, nos termos do art. 1.332 do mesmo diploma, a incidência dos princípios da taxatividade e da tipicidade às obrigações propter rem no âmbito da gestão da vida condominial.

\section{REFERÊNCIAS}

ABERKANE, Hassen. Essai d'une théorie générale de l'obligation propter rem en droit positif français. Paris: Librairie Générale de Droit et de Jurisprudence, 1957.

ARAÚJO, Bárbara Almeida de. As Obrigações propter rem. In Obrigações: Estudos na Perspectiva Civil-constitucional (Gustavo Tepedino, coord.), Rio de Janeiro: Renovar, 2005.

ASCENSÃO, José de Oliveira. A Tipicidade dos Direitos Reais. Lisboa: Livraria Petrony, 1968. Direitos Reais. Lisboa: Quid Juris, 1978.

AZEVEDO, Antonio Junqueira de. Restrições Convencionais de Loteamento - Obrigações Propter Rem e suas Condições de Persistência. Base do Negócio Jurídico e seu desaparecimento em ato 
normativo negocial. Sucessão e leis municipais e interpretação teleológica. Interpretação conforme a Constituição e princípio da igualdade. In: Estudos e Pareceres de Direito Privado. São Paulo: Saraiva, 2004.

BALBI, Giovanni. Le obbligazioni propter rem. Torino: G. Giappichelli, 1950.

CÂNFORA, Roxana B. Obligaciones Reales. Rosário: Editorial Juris, 1996.

COMPORTI, Marco. Contributo allo studio del diritto reale. Milano: Giuffrè, 1977.

CORDEIRO, Menezes. Direitos Reais, Lisboa: Lex, 1993.

DANTAS, San Tiago. O conflito de vizinhança e sua composição. Rio de Janeiro: Forense, 1972.

DIEZ-PICAZO, Luis. Fundamentos del Derecho Civil Patrimonial. Madrid: Civitas, 1996. v. 1.

ESPÍNOLA, Eduardo. Sistema do Direito Civil Brasileiro. Rio de Janeiro: Freitas Bastos, 1944.

GOMES, Orlando. Contratos. Rio de Janeiro: Forense, 2007.

GONDINHO, André Pinto da Rocha Osório. Direitos Reais e Autonomia da Vontade: o princípio da tipicidade dos direitos reais. Rio de Janeiro: Renovar, 2001.

LOPES, João Batista. Condomínio. São Paulo: Revista dos Tribunais, 2003.

MAIA, Paulo Carneiro. Obrigação 'propter rem', In: Obrigações e contratos. São Paulo Revista dos Tribunais, 2011. v. 1.

MAURO, Roberta. Teoria Geral dos Direitos Reais. Rio de Janeiro, Revista dos Tribunais, 2013.

Relações Obrigacionais e Relações Reais: propostas para uma nova delimitação de suas fronteiras. In: Obrigações: estudos na perspectiva civil-constitucional (Gustavo Tepedino, coord.), Rio de Janeiro: Renovar, 2005.

MESQUITA, Manuel Henrique. Obrigações Reais e Ônus Reais. Coimbra: Almedina, 2000.

MESSINEO, Francesco. Manuale di Diritto Civile e Commerciale. Milano: Giuffrè, 1959.

MIRANDA, Pontes de. Tratado de Direito Privado. São Paulo: Revista dos Tribunais, 2012. Tratado de Direito Privado. São Paulo: Revista dos Tribunais, 2012. t. XI.

NASCIMENTO, Tupinambá Miguel Castro do. Posse e Propriedade. Porto Alegre: Livraria do Advogado Editora, 2003.

NATUCCI, Alessandro. La tipicità dei diritti realli. Padova: Cedam, 1988.

NONATO, Orozimbo. Curso de Obrigações: generalidades e espécies. Rio de Janeiro: Forense, 1959. v. 1. 
OLIVA, Milena Donato. A Responsabilidade do Adquirente pelos Encargos Condominiais na Propriedade Horizontal. Revista Trimestral de Direito Civil, ano 7, vol. 26, 2006.

OLIVA, Milena Donato; RENTERIA, Pablo. Autonomia privada e direitos reais: redimensionamento dos princípios da taxatividade e da tipicidade no direito brasileiro. Revista Civilística, a. 5. n. 2. 2016.

Tutela do consumidor na perspectiva civil-constitucional: a cláusula geral de boa-fé objetiva nas situações jurídicas obrigacionais e reais e os Enunciados 302 e 308 da Súmula da Jurisprudência Predominante do Superior Tribunal de Justiça. Revista de Direito do Consumidor, v.101, 2015.

PEREIRA, Caio Mário da Silva. Condomínio e Incorporações. Rio de Janeiro: Forense, 2002. Instituições de Direito Civil. Rio de Janeiro: Forense, 2016. v. 2.

PERLINGIERI, Pietro. Perfis do Direito Civil: Introdução ao Direito Civil Constitucional, Rio de Janeiro: Renovar, 2002.

RENTERIA, Pablo. Penhor e Autonomia privada. São Paulo: Atlas, 2016.

SANTOS JÚNIOR, E. Da Responsabilidade Civil de Terceiro por Lesão do Direito de Crédito. Coimbra: Ed. Livraria Almedina, 2003.

SARMENTO FILHO, Eduardo Sócrates Castanheira. A Responsabilidade pelo pagamento de Quotas Condominiais no Regime de Propriedade Horizontal. São Paulo: Advocacia Dinâmica Seleções Jurídicas, 1998.

SCAPEL, Julien. La notion d'obligation réelle. Aix-en-Provence: Presses Universitaires D'AixMarseille, Faculté de Droit et de Science Politique, 2002.

SCHREIBER, Anderson; TEPEDINO, Gustavo. Direito das Obrigações. São Paulo: Atlas, 2003. v. 4.

SERPA LOPES, Miguel Maria de. Curso de Direito Civil. Rio de Janeiro: Freitas Bastos, 1966. v. 2.

TEIXEIRA DE FREITAS, Augusto. Consolidação das Leis Civis. Rio de Janeiro: Editora Garnier, 1910.

TEPEDINO, Gustavo. Autonomia Privada e Obrigações Reais. In: Temas de Direito Civil. Rio de Janeiro: Renovar, 2006. t. II.

Multipropriedade imobiliária. São Paulo: Saraiva, 1993.

Teoria dos bens e situações subjetivas reais: esboço de uma introdução. In: Temas de direito civil. Rio de Janeiro: Renovar, 2006. t. II.

TRABUCCHI, Alberto. Istituzioni di Diritto Civile. Padova: Cedam, 1993.

VARELA, Antunes. Das Obrigações em Geral. Coimbra: Almedina, 2000. v. 1.

Trabalho enviado em 19 de fevereiro de 2017.

Aceito em 06 de abril de 2017. 